\title{
Penguatan pendidikan karakter model social problem-solving bagi siswa sekolah dasar
}

\author{
Sintha Wahjusaputri *, Bunyamin Bunyamin, Tashia Indah Nastiti \\ Administrasi Pendidikan, Universitas Muhammadiyah Prof. DR. HAMKA, Jakarta \\ Jalan Warung Buncit Raya No. 17, Pancoran Jakarta Selatan, Indonesia \\ * Corresponding Author. Email: sinthaw@uhamka.ac.id \\ Received: 29 September 2019; Revised: 18 October 2019; Accepted: 20 October 2019
}

\begin{abstract}
Abstrak
Tujuan kegiatan pengabdian masyarakat ini untuk mengetahui langkah-langkah penguatan model pendidikan karakter bagi Siswa SD Muhammadiyah 11 Tanjung Lengkong Jakarta dan penerapannya. Metode yang digunakan metode Research and Development (RED) terdiri dari empat tahapan, yaitu: (1) Tahap pendahuluan merupakan tahap kegiatan awal dan pengumpulan informasi siswa; (2) Tahap perencanaan model pendidikan karakter bagi siswa sebagai pengembangan bentuk produk awal; (3) Tahap uji coba, evaluasi dan revisi, dan (4) Tahap implementasi pendidikan karakter. Untuk mengukur kesuksesan penerapan pendidikan karakter menggunakan teknik Delphi. Berdasarkan penilaian para ahli (expert judgment) bahwa penguatan model pendidikan karakter siswa SD Muhammadiyah 11 diukur menggunakan model Social problemsolving (SPS). Hasil temuan penguatan model pendidikan karakter yaitu pada peningkatan keterampilan sosial siswa SD Muhammadiyah 11 Tanjung Lengkong makin baik dengan peningkatan rata-rata skor 3,75. Oleh karena itu penggunaan Model Social problem-solving layak digunakan.
\end{abstract}

Kata Kunci: pendidikan karakter, model social problem-solving, SD Muhammadiyah Tanjung Lengkong 11 Jakarta

\section{Strengthening character education model social problem-solving for elementary school students}

\begin{abstract}
The purpose of community service activities to know how to strengthen the character education model for elementary school students of Muhammadiyah 11 Tanjung Lengkong Jakarta and its application. Research and Development $(R \mathcal{E} D)$ used for the research method, there are consist of four step: (1) the preliminary step is the firs activity and collecting student information; (2) The planning stage of character education model for students as the development of initial product form; (3) Trial, evaluation and revision phases, and (4) Implementation step of character education. To measure the successful implementation of character education using the Delphi technique. Based on expert judgment, the strengthening of character education model of SD Muhammadiyah 11 Tanjung Lengkong Jakarta can be measured using the social problem-solving model. The result of the strengthening of character education model was found on the social skills enhancement of elementary school students of Muhammadiyah 11 Tanjung Lengkong with an average score of 3,75. Therefore the use of Model Social problem-solving is worth using.
\end{abstract}

Keywords: character education, social model problem solving, SD Muhammadiyah Tanjung 11, Jakarta

How to Cite: Wahjusaputri, S., Bunyamin, B., \& Nastiti, T. (2019). Penguatan pendidikan karakter model social problem solving bagi siswa sekolah dasar. JPPM (Jurnal Pendidikan dan Pemberdayaan Masyarakat), 6(2), 119-130. doi:https://doi.org/10.21831/jppm.v6i2.27371

dofi https://doi.org/10.21831/jppm.v6i2.27371

\section{PENDAHULUAN}

Pendidikan karakter ditempatkan sebagai landasan untuk mewujudkan visi pem- bangunan nasional (Ahmad, 2019; Hanani, 2016), yaitu mewujudkan masyarakat Indonesia yang berakhlak mulia, bermoral, beretika, berbudaya, dan beradab berdasarkan falsafah 
Pancasila. Fakta menunjukkan bahwa karakter bangsa pada era globalisasi merosot dengan sangat tajam, hal inilah yang melatarbelakangi munculnya pendidikan karakter (Mansyur, 2017; Uyun, 2012). Pendidikan dianggap sebagai suatu media yang paling jitu dalam mengembangkan potensi siswa baik berupa keterampilan maupun wawasan. Oleh karena itu, pendidikan secara terus-menerus dibangun dan dikembangkan agar proses pelaksanaannya menghasilkan generasi yang diharapkan. Maka perbaikan sumber daya manusia juga perlu ditingkatkan, agar mampu menghasilkan sumber daya yang cerdas, terampil, mandiri dan berakhlak mulia terus diupayakan melalui proses pendidikan.

Pembangunan karakter dan jati diri bangsa merupakan cita-cita luhur yang harus diwujudkan melalui penyelenggaraan pendidikan yang terarah dan berkelanjutan. Penanaman nilai-nilai akhlak, moral, dan budi pekerti seperti tertuang dalam Undangundang Republik Indonesia No 20 Tahun 2003 tentang "Sistem Pendidikan Nasional harus menjadi dasar pijakan utama dalam mendesain, melaksanakan, dan mengevaluasi sistem pendidikan nasional". Kepercayaan ini mendorong setiap orang untuk siap menghadapi tantangan global abad-21. Dalam konteks ini, pemerintah Indonesia percaya bahwa mempersiapkan generasi muda adalah satu-satunya cara untuk menjadi bangsa yang sangat kuat di tahun 2045. (Rokhman et al., 2014). Karakter merupakan sifat-sifat kejiwaan, akhlak atau budi pekerti yang membedakan seorang dari yang lain. Bangsa yang maju adalah bangsa yang memiliki karakter unggul. Karakter dianggap sebagai bagian dari unsur psiko-sosial yang berkaitan dengan konteks sekitarnya (Koesoema, 2007, p. 79). Karakter juga dapat dianggap sebagai unsur perilaku yang dimiliki oleh manusia. Karakter biasanya terlihat dari sudut pandang psikologis. Hal ini terkait dengan aspek perilaku, sikap, cara dan kualitas yang membedakan satu orang ke elemen lain atau unsur spesifik yang dapat menyebabkan seseorang menjadi lebih menonjol dari orang lain. Karakter adalah bagian dari elemen khusus manusia yang mencakup kemampuan mereka untuk menghadapi tantangan dan kesulitan yang dihadapi. Dengan demikian, karakter mencakup nilai moral, sikap, dan perilaku (Pemerintah Republik Indonesia, 2010). Seseorang dianggap memiliki karakter yang baik dari sikap dan tindakan yang dilakukan mencerminkan karakter tertentu. Oleh karena itu, karakter terlihat atau tercermin dari kebiasaan kehidupan manusia sehari-hari. Menurut (Cronbach, 1977; Knox, 1966, p. 57) mengatakan bahwa, karakter adalah aspek dari kepribadian. Aspek kepribadian meliputi kepercayaan, perasaan, dan tindakan yang dapat dihubungkan untuk mengubah karakter seseorang dengan mengatur kepribadian orang tersebut. Pembentukan karakter tidak akan efektif jika aspek kepribadian tidak dapat diintegrasikan dengan sistem kepercayaan yang diberikan oleh seseorang kepada dirinya dengan baik. Karakter, seperti yang disebutkan oleh (Cronbach, 1977), bukanlah suatu kesatuan yang memisahkan kebiasaan dan keinginan seseorang untuk berkomitmen dalam melaksanakan sesuatu kepercayaan yang diberikan kepadanya. Menurut (Goleman, 2007, p.35) mengatakan bahwa pendidikan karakter mencakup aspek pengetahuan (kognitif), perilaku, perasaan, dan tindakan yang saling terkait satu sama lain sehingga jika seseorang ingin mengubah karaktenya, mereka perlu mengatur ulang elemen dasar karakter mereka. Berbeda pendapat dari Cronbach dan Goleman, menurut (Lickona et al., 2007), penddikan karakter terbentuk dari tiga elemen, yaitu: moral, perasaan, dan tindakan. Moral mencakup kesadaran moral, pengetahuan tentang nilai-nilai moral, pandangan ke depan, penalaran moral, pengambilan keputusan, dan kesadaran diri, adalah hal yang penting untuk diajarkan kepada siswa. Lebih lanjut lagi ke perasaan moral, termasuk: hati nurani, keyakinan, empati, kebaikan, pengendalian diri, dan kerendahan hati, kemudian ke tahap yang paling signifikan, yaitu tindakan moral. Hal ini penting karena pada tahap ini kekuatan pendorong bagi seseorang dalam melakukan hal yang baik dapat dilihat dari kemampuan, kainginan, dan praktek. Sinergi dari ketiga komponen moral saling berhubungan dan merupakan implementasi yang diperlukan dari pendidikan karakter dalam mengembangkan kecerdasan moral siswa. Baik Goleman dan Lickona menyadari bahwa pendidikan karak- 
JPPM (Jurnal Pendidikan dan Pemberdayaan Masyarakat), 6 (2), 2019 - 121

Sintha Wahjusaputri, Bunyamin Bunyamin, Tashia Indah Nastiti

ter adalah kesatuan yang terpadu dari aspek dasar bagi seorang siswa. Lingkungan menjadi aspek penting dalam pendidikan karakter untuk membangun masyarakat yang sadar dan peka terhadap lingkungan dan kompleksitas, serta untuk memungkinkan siswa memperoleh pengetahuan, keterampilan, sikap, motivasi, dan kemauan untuk bekerja sama sebagai individu dan kelompok terhadap tindakan preventif dan solusi masalah lingkungan. Berdasarkan ketiga unsur tersebut seseorang dianggap memiliki karakter yang baik jika mereka tahu tentang hal-hal yang baik (moral yang baik), memiliki minat terhadap hal yang baik (perasaan) dan berbuat baik (tindakan). Ketiga unsur itu akan menuntun seseorang untuk memiliki kebiasaan baik dalam berpikir, merasakan, dan bertindak terhadap TuhanNya sebagai pencipta, komunitas pertemanan, teman, lingkungan, dan rasa kebangsaan terhadap tanah air. Lebih lanjut dikatakan oleh (Lickona et al., 2007), mengatakan bahwa anak memerlukan perhatian, kasih sayang yang lebih spesifik, baik itu di lingkungan rumah dan sekolah.

Pendidikan karakter dibentuk pada lingkungan internal maupun eksternal seseorang. Pendidikan karakter pada lingkungan internal dimulai dari lingkungan keluarga inti. Sedangkan lingkungan eksternal meliputi lingkungan masyarakat dan lingkungan sekolah. Maka dari itu harus adanya kerja sama antara pihak didalam lingkungan internal maupun lingkungan eksternal. Menurut (Lickona et al., 2007) menulis sepuluh (10) prinisip pendidikan karakter di tahun 1995 yang kemudian direvisi dan dikembangkan oleh (Doty \& Sowden, 2010), terdiri dari: (1) Sekolah dengan seluruh komunitasnya baik kepala sekolah, tenaga pendidik dan tenaga kependidikan mengembangkan nilai etika dasar (promote core values) dan perilaku kepada peserta didik yang diyakini sebagai karakter yang baik; (2) Sekolah mendefinisikan karakter secara komprehensif meliputi cara berpikir, bersikap dan berperilaku (Defines Character" to include thinking, feeling and doing) untuk melakukan pekerjaan yang terbaik; (3) Sekolah menggunakan pendekatan yang komprehensif (Uses a comprehensive approach) secara mendalam dan proaktif untuk mengembangkan karakter peserta didik;
(4) Sekolah mengembangkan komunitas yang peduli dan bertanggung jawab satu sama lain (creates a carring community) baik dari pihak sekolah, peserta didik dan pihak orang tua peserta didik; (5) Sekolah memberikan kesempatan kepada peserta didik untuk mengekspresikan nilai-nilai moral (Provides students with opportunities for moral action) yang diyakini sebagai karakter yang baik; (6) Sekolah membantu peserta didik dalam mengembangkan/menumbuhkan motivasi diri (Fosters students' self-motivation) dalam melakukan perbuatan yang baik; (7) Sekolah mengembangkan kurikulum yang bermakna dan menantang (offers a meaningful and challenging academic curriculum) yang memiliki rasa saling menghormati kepada semua peserta didik, mengembangkan nilai etika yang baik serta membantu peserta didik untuk menjadi sukses; (8) Staf sekolah merupakan komunitas belajar (Engages staff as a learning community) bagi peserta didik dalam pengembangan nilai etika, perilaku dan suri tauladan yang baik; (9) Sekolah mengembangkan kepemimpinan bersama yang memberikan berbagai pendukung pendidikan karakter bagi peserta didik; (10) Sekolah melibatkan komunitas sekolah dan orang tua murid sebagai mitra (Engages families and community members as partners) dalam kegiatan pengembangan pendidikan karakter; (11) Sekolah secara regular melakukan evaluasi terhadap staf, budaya sekolah dan iklim sekolah (Assesses the culture and climate of the school) dalam meningkatkan pendidikan karakter agar peserta didik memiliki karakter yang baik. (character.org, 2014, p. 35).

Upaya untuk mengimplementasikan pendidikan karakter melalui Pendekatan Holistik, yaitu mengintegrasikan perkembangan karakter ke dalam setiap aspek kehidupan sekolah. Berikut ini ciri-ciri pendekatan holistik, yaitu: (1) Segala sesuatu di sekolah diatur berdasarkan perkembangan hubungan antara peserta didik, guru, dan masyarakat. Sekolah merupakan masyarakat siswa yang peduli di mana ada ikatan yang jelas yang menghubungkan siswa, guru, dan sekolah; (2) Pembelajaran emosional dan sosial setara dengan pembelajaran akademik. Kerjasama dan kolaborasi di antara siswa menjadi hal yang lebih utama dibandingkan persaingan. Nilai- 
JPPM (Jurnal Pendidikan dan Pemberdayaan Masyarakat), 6 (2), 2019 - 122

Sintha Wahjusaputri, Bunyamin Bunyamin, Tashia Indah Nastiti

nilai seperti keadilan, rasa hormat, dan kejujuran menjadi bagian pembelajaran seharihari baik di dalam maupun di luar kelas siswa diberikan banyak kesempatan untuk mempraktekkan prilaku moralnya melalui kegiatan-kegiatan seperti pembelajaran memberikan pelayanan; (3) Disiplin dan pengelolaan kelas menjadi fokus dalam memecahkan masalah dibandingkan hadiah dan hukuman. Model pembelajaran yang berpusat pada guru harus ditinggalkan dan beralih ke kelas demokrasi di mana guru dan siswa berkumpul untuk membangun kesatuan, Norma, dan memecahkan masalah (Elkind \& Sweet, 2004). Menurut Boe et al. (2015), dari hasil penelitiannya menemukan bahwa ada dua belas (12) kekuatan karakter yang penting dimiliki oleh peserta didik di sekolah, yaitu: kepemimpinan, integritas, ketekunan, keberanian, keterbukaan, keadilan, cinta tanah air, regulasi diri, cinta belajar, kecerdasan sosial, perspektif dan kreativitas. Pendidikan di sekolah merupakan salah satu faktor menentukan kualitas seseorang, dengan cara membangun Intelegence, Emotional dan Spiritual Quation (IESQ). Salah satu cara yang dapat digunakan membentuk dasar karakter adalah melalui nilai budaya dan iklim sekolah, karena nilai budaya dan iklim sekolah akan melekat pada diri seseorang dan menjadi literasi pembiasaan karakter yang baik (Ferdiawan \& Putra, 2013). Menurut Bialik et al. (2015), menyatakan bahwa pendidikan karakter akan kuat melalui perbuatan yang baik dilihat dari kualitas, nilai (cita-cita dan konsep) dan kemampuan untuk membuat pilihan yang bijak dalam kehidupannya di tengah masyarakat. Lebih lanjut dikatakan oleh Bialik et al. (2015, p. 2), bahwa tujuan luas pendidikan karakter adalah: (1) membangun fondasi bagi pembelajaran seumur hidup; (2) mendukung hubungan yang baik di rumah, di lingkungan masyarakat dan di tempat kerja; (3) mengembangkan nilai-nilai diri dan kebaikan dalam dunia global. Berdasarkan uraian karakter tersebut menunjukkan nilai religious dan disiplin harus tumbuh dalam diri seseorang. Nilai religious dan disiplin perlu diajarkan kepada siswa sejak pendidikan dasar, karena dengan praktikpraktik pendidikan karakter siswa akan terbangun pikiran, perkataaan dan tindakan.
SD Muhammadiyah 11, Tanjung Lengkong, Jakarta merupakan Sekolah Binaan Yayasan Muhammadiyah, sekolah yang berbasis pendidikan agama Islam sangat menerapkan nilai-nilai pendidikan karakter, sesuai visi bahwa, menciptakan peserta didik yang cerdas, berakhlaq dan siap bersaing di era global dan misi yang dilakukan oleh SD Muhammadiyah 11, Tanjung Lengkong, Kemayoran Jakarta adalah: (1) mengembangkan kompetensi spiritual, sosial, pengetahuan dan keterampilan; (2) melaksanakan pembelajaran dengan pendekatan saintifik; (3) meningkatkan kualitas pembelajaran dengan multimedia; (4) membentuk peserta didik berakhlaq mulia; (5) membimbing peserta didik peduli lingkungan.

Secara individu, karakter lahir tetapi tidak berfungsi sebagai karakter bangsa. Karakter bangsa tidak lahir. Karakter bangsa akan menjadi kuat jika karakter individu orang tersebut juga kuat (Koellhoffer, 2009). Aspek terpenting di dalam pembentukan kekuatan karakter bangsa bagi generasi muda dengan cara menanamkan atau menumbuhkan rasa kebangsaan terhadap tanah airnya. Generasi muda merupakan agen perubahan suatu Negara/bangsa. Generasi muda tidak mengalami proses menumbuhkan karakter bangsa dari awal seperti yang dilakukan oleh para pemimpin dimasa lalu. Tanpa tindakana untuk menghayati dan mensosialisasikan nilai karakter bangsa, kekuatan karakter kebangsaan yang dimiliki oleh generasi mudah akan lemah dalam membangun Negara. Dengan demikian, penguatan pendidikan karakter sangat penting digelorakan/ditumbuhkan pada diri generasi muda.

Model penguatan pendidikan karakter dalam kegiatan pengabdian masyarakat dalam penguatan pendidikan karakter kepada siswa SD Muhammadiyah 11 Tanjung Lengkong melalui keterampilan sosial pada mata pelajaran seni budaya dan keterampilan dengan menggunakan model Social problemsolving (SPS), dimana model pendidikan melalui keterampilan sosial akan lebih efektif apabila kegiatannya tidak terlalu formal, waktu kegiatan disesuaikan dengan waktu luang siswa, dan adanya tindak lanjut secara kongkrit setelah kegiatan pelatihan dalam rangka penguatan pendidikan karakter ini 
JPPM (Jurnal Pendidikan dan Pemberdayaan Masyarakat), 6 (2), 2019 - 123

Sintha Wahjusaputri, Bunyamin Bunyamin, Tashia Indah Nastiti

selesai. Pengembangan penguatan pendidikan karakter pada siswa SD Muhammadiyah 11 Tanjung Lengkong Jakarta dengan menggunakan model social problem-solving (SPS) lebih difokuskan pada pengembangan model berbasis pemecahan masalah atau problem solving yang berhubungan dengan permasalahan diri siswa dan lingkungan sekolahnya. Hakikat masalah adalah gap atau kesenjangan antara situasi nyata dan kondisi yang diharapkan, atau antara kenyataan yang terjadi dengan apa yang diharapkan (Sanjaya, 2015, p. 216). Dalam kegiatan pembelajaran di sekolah, kesenjangan tersebut bisa dirasakan dari adanya keresahan, keluhan, kerisauan dan kecemasan. Oleh karena itu penguatan pendidikan karakter melalui keterampilan sosial dalam pengabdian masyarakat ini diberikan pada materi pelajaran keterampilan sosial dan budaya dengan topik tidak terbatas pada materi pelajaran yang bersumber buku saja, akan tetapi bersumber dari peristiwa-peristiwa tertentu sesuai dengan kurikulum yang berlaku.

\section{METODE}

Metode kegiatan pengabdian masyarakat ini, penulis menggunakan metode Research and Development (R\&D). Menurut Gall et al. (2003) bahwa model Research and Development adalah model yang bertujuan untuk meningkatkan kualitas pendidikan, khususnya pendidikan karakter. Dalam kegiatan pengabdian masyarakat ini, Research and Development dimanfaat untuk menghasilkan penguatan model pendidikan karakter sebagai dalam mata pelajaran seni budaya dan keterampilan siswa SD Muhammadiyah 11 Tanjung Lengkong Jakarta, yang terdiri dari empat tahapan, yaitu: (1) tahap pendahuluan merupakan tahap kegiatan awal dan pengumpulan informasi siswa; (2) tahap perencanaan model pendidikan karakter bagi siswa sebagai pengembangan bentuk produk awal; (3) tahap uji coba, evaluasi dan revisi, dan (4) tahap implementasi pendidikan karakter. Untuk mengukur kesuksesan penerapan pendidikan karakter menggunakan teknik Delphi.

Teknik pengumpulan data yang digunakan dalam kegiatan pengabdian masyarakat ini melalui: (1) Focus Group Discussion (FGD); (2) Pengamatan partisipasi atau observasi; (3) Wawancara; dan (4) dokumentasi. Setelah pelaksanaan Focus Group Discussion (FGD) selanjutnya melakukan validasi model. Kegiatan Focus Group Discussion (FGD) melibatkan 12 orang ahli (expert judgment) terdiri dari 2 orang dosen Tim pengabdi masyarakat, 2 orang mahasiswa pengabdi; 1 kepala sekolah, 3 guru ahli pendidikan karakter, 3 guru ahli teknologi pembelajaran dan 1 staf administrasi dan jumlah siswa 28 orang, mencakup kelas 1-6 pendidikan dasar.

Teknik pengumpulan data menggunakan teknik FGD (Forum Group Discussion) dan angket. Validitas data menggunakan validasi ahli dengan teknik Delphi. Analisis data menggunakan analisis kuantitatif dengan teknik analisis deskriptif. Salah satu fungsi dari analisis deskriptif adalah menyajikan data hasil penelitian dalam bentuk yang sederhana sehingga mudah mendapatkan gambaran hasil penelitian. Teknik analisis data secara kualitatif dilakukan untuk kepentingan pemaknaan dengan menganalisis data hasil validasi (penilaian) dari para ahli (expert) yang telah memberikan masukanmasukan yang berguna untuk perbaikan model pendidikan karakter beserta kelengkapannya.

\section{HASIL DAN PEMBAHASAN}

Kegiatan pengabdian masyarakat dalam penguatan pendidikan karakter berusaha untuk meningkatkan keterampilan sosial (soft skill) siswa SD Muhammadiyah 11 Tanjung Lengkong Jakarta dengan menggunakan model pembelajaran berbasis masalah ( $p r o b-$ lem solving), yaitu model Social problemsolving (SPS). Model Social problem-solving (SPS) mendidik siswa untuk berpikir secara sistematis segala permasalahan yang dihadapinya, melatih siswa untuk mendisain suatu penemuan, berpikir dan bertindak secara kreatif, memecahkan masalah yang dihadapi secara realistik, mengidentifikasi dan melakukan penyelidikan, menafsirkan dan mengevaluasi hasil pengamatan dalam materi pembelajaran, merangsang perkembangan kemajuan berfikir siswa untuk menyelesaikan masalah yang dihadapi dengan tepat, dapat membuat pendidikan sekolah lebih relevan dengan kehidupan, mampu mencari berbagai jalan keluar dari kesulitan yang dihadapi, 
JPPM (Jurnal Pendidikan dan Pemberdayaan Masyarakat), 6 (2), 2019 - 124

Sintha Wahjusaputri, Bunyamin Bunyamin, Tashia Indah Nastiti

belajar menganalisis suatu masalah dari berbagai aspek dan mendidik siswa percaya diri akan kemampuan yang dimilikinya.

Model Social problem-solving (SPS) dilaksanakan melalui kegiatan terpadu yakni peningkatan keterampilan sosial dengan menciptakan kreasi permasalahan materi belajar dalam bentuk puzzle. Hal ini untuk melatih keterampilan sosial siswa SD Muhammadiyah 11 Tanjung Lengkong Jakarta menggali permasalahan yang ada dalam lingkungannya. Adapun permasalah pendidikan karakter untuk pada siswa SD Muhammadiyah 11 Tanjung Lengkong Jakarta dapat digambarkan menggunakan tulang ikan (fishbone) (Gambar 1).

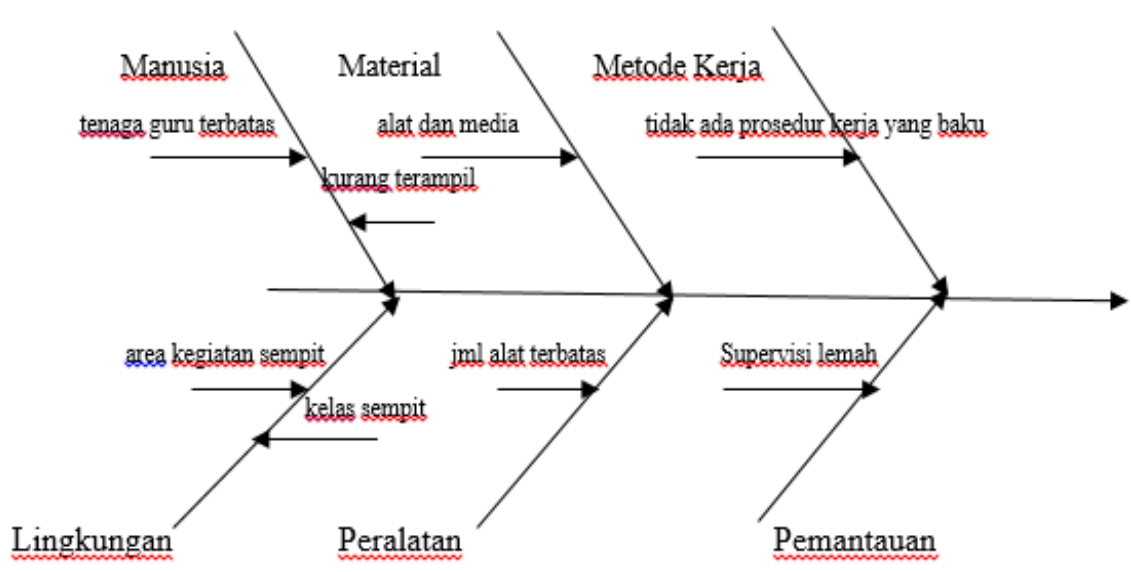

Sebab

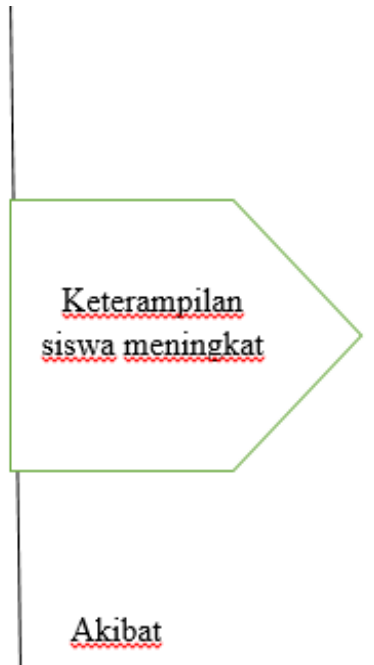

Akibat

Gambar 1. Fishbone Permasalahan Pendidikan Karakter

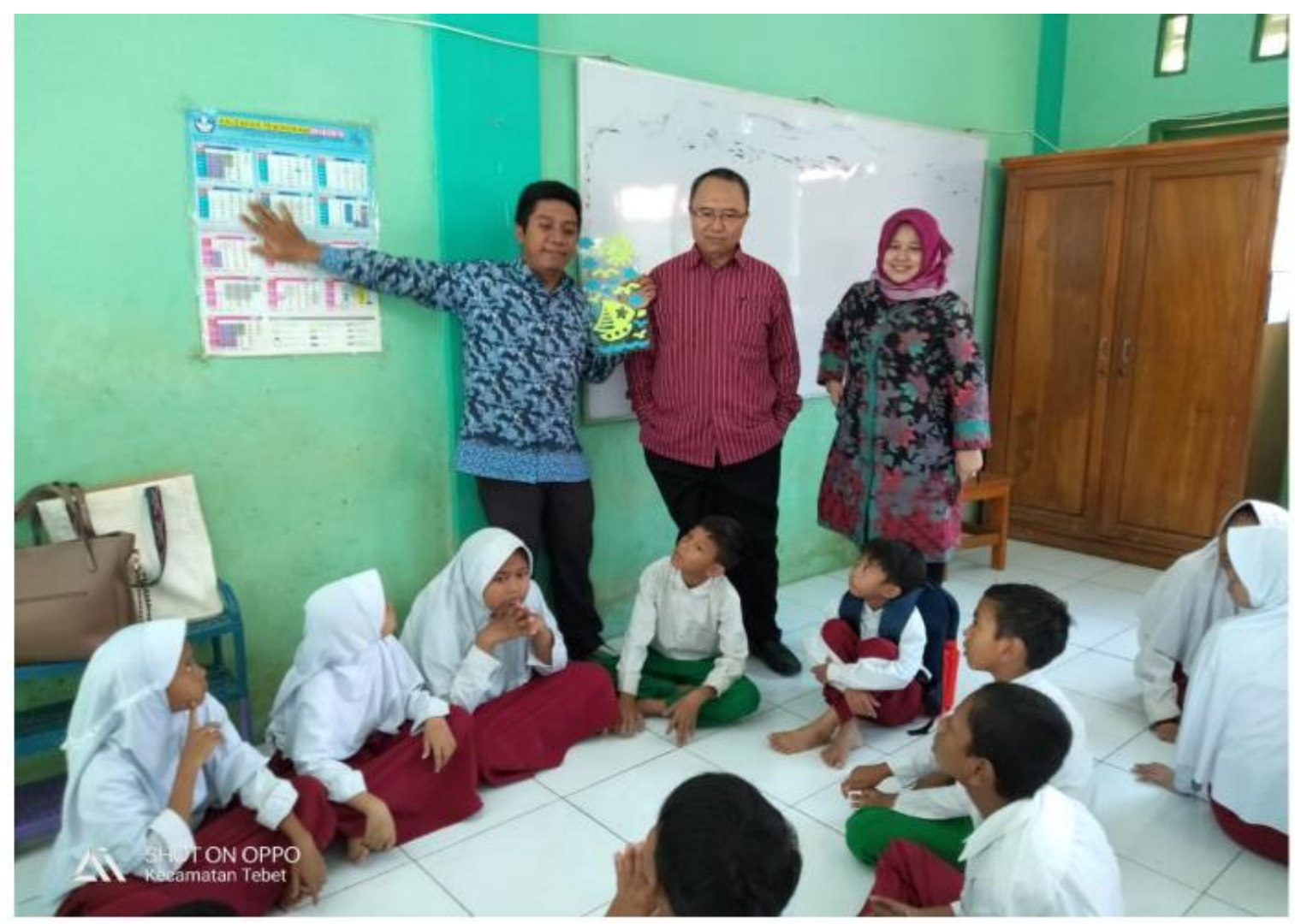

Gambar 2. Tim Pengabdi memberikan penguatan pendidikan karakter pada siswa SD Muhammadiyah 11 Tanjung Lengkong Jakarta 
JPPM (Jurnal Pendidikan dan Pemberdayaan Masyarakat), 6 (2), 2019 - 125

Sintha Wahjusaputri, Bunyamin Bunyamin, Tashia Indah Nastiti

Solusi yang diberikan untuk mengatasi permasalahan tersebut yaitu: Pertama, memberikan pendampingan, pembinaan dan penguatan kepada siswa dalam pembentukan pendidikan karakter dengan mengaplikasikan secara langsung tiga aspek pendidikan karakter kedalam diri peseta didik, yaitu tentang hal-hal yang baik (moral yang baik), memiliki minat terhadap hal yang baik (perasaan) dan berbuat baik (tindakan). Ketiga unsur itu akan menuntun seseorang untuk memiliki kebiasaan baik dalam berpikir, merasakan, dan bertindak terhadap TuhanNya sebagai pencipta, komunitas pertemanan, teman, lingkungan, dan rasa kebangsaan terhadap tanah air. Kedua, memberikan sosialisasi, pembinaan dan pembelajaran parenting kepada orang tua dilingkungan SD Muhammadiyah 11, Tanjung Lengkong, Kemayoran Jakarta sebagai program keberlanjutan PKM.

Kegiatan ini melibatkan siswa yang akan diberikan pendampingan penguatan pendidikan karakter berjumlah berjumlah 28 siswa yang terdiri dari kelas 1-6, guru pendamping kelas 12 guru. Metode penyelesaian masalah melalui metode social problemsolving (SPS) dilakukan dengan pendekatan, ceramah bervariasi dan demonstrasi. Validasi terhadap kejelasan model pendidikan karakter dengan menggunakan model social problem-solving sebagai model pembelajaran berbasis masalah dalam metode R\&D adalah uji coba pendahuluan oleh ahli (guru) yang terdiri dari 7 orang, yaitu 3 guru ahli pendidikan karakter, 2 guru ahli teknologi pembelajaran dan 2 guru ahli evaluasi. Penilaian menggunakan skala linkert, dengan skor terendah 1 dan skor tertinggi 5. Rerata skor hasil penilaian tahap pertama terhadap keterbacaan instrumen kualitas pembelajaran seni budaya dan keterampilan adalah seperti pada Tabel 1 .

Apabila dikonsultasikan dengan standar penilaian dalam panduan model pendidikan karakter, maka rerata skor total berada pada interval lebih besar dari 3.4-4.oo termasuk katagori baik atau layak sehingga model SPS dapat digunakan dengan beberapa perbaikan. Untuk mendapatkan model yang lebih baik, maka instrumen tetap dilakukan perbaikan. Dengan demikian, sebelum ins- trumen di uji coba pada tahap kedua uji coba skala kecil, maka terlebih dahulu dilakukan perbaikan mengacu pada rekomendasi yang diberikan oleh validator. Perbaikan mengacu pada 5 rekomendasi oleh para validator dalam skala kecil dalam uji kelayakan atau kejelasan penerapan panduan model SPS pada penguatan pendidikan karakter pada siswa SD Muhammadiyah 11 Tanjung Lengkong Jakarta (McDermott et al., 2004). Model pendidikan karakter divalidasi dari segi objektivitas, kepraktisan dan efisiensi. Penilai model pendidikan karakter atau kejelasan panduan model SPS yang terlibat dalam pengembangan tahap uji coba pertama oleh ahli (guru) yang terdiri dari 7 orang, yaitu 3 guru ahli pendidikan karakter, 2 guru ahli teknologi pembelajaran dan 2 guru ahli evaluasi. Penilaian menggunakan skala linkert, dengan skor terendah 1 dan skor tertinggi 5 . Rerata skor hasil penilaian tahap pertama terhadap model evaluasi pendidikan karakter seperti pada Tabel 2.

Berdasarkan hasil pada Tabel 2, maka dapat peneliti bertujuan untuk mengembangkan pola mengajar untuk memberikan penguatan pendidikan karakter yang diinginkan menggunakan teknik Delphi sebagai prosedur penelitian dalam pengumpulan data. Setelah tiga putaran menanggapi 3 kuesioner, 7 ahli memberikan pendapat konsensus yang disajikan sebagai berikut. Pada putaran pertama menjawab kuesioner, para ahli diminta untuk berpendapat Apakah mereka setuju atau tidak setuju dengan kerangka untuk pengembangan pola mengajar untuk penguatan pendidikan karakter yang diinginkan sesuai dengan mata pelajaran seni budaya dan keterampilan. Hasil analisis tanggapan ahli (expert judgment) menunjukkan bahwa setidaknya 90\% dari para ahli memberikan respon positif untuk setiap titik pada kuesioner. Tim Pengabdi kemudian membuat penyesuaian draft kuesioner pertama sesuai dengan saran mereka dan menambahkan beberapa rincian lebih lanjut untuk beberapa pertanyaan sesuai dengan tujuan kegiatan pengabdian dalam keterampilan sosial yang diberikan kepada siswa SD Muhammadiyah 11 Jakarta. 
JPPM (Jurnal Pendidikan dan Pemberdayaan Masyarakat), 6 (2), 2019 - 126

Sintha Wahjusaputri, Bunyamin Bunyamin, Tashia Indah Nastiti

Tabel 1. Hasil Penilaian Terhadap Panduan Model Pendidikan Karakter Model SPS

\begin{tabular}{clc}
\hline No. & \multicolumn{1}{c}{ Aspek Penilaian } & Rerata Skor \\
\hline 1. & Kejelasan kriteria pembelajaran seni budaya dan keterampilan & 3.75 \\
2. & Kejelasan perumusan tujuan pembelajaran & 3.78 \\
3. & Kejelasan perumusan materi pembelajaran & 3.85 \\
4. & Cakupan materi pembelajaran & 3.65 \\
5. & Kejelasan desain pembelajaran & 3.85 \\
6. & Kejelasan model pembelajaran & 3.87 \\
7. & Kejelasan peran pendidikan & 3.88 \\
8. & Kejelasan instrumen penilaian & $3 \cdot 78$ \\
9. & Kejelasan kriteria penilaian & 3.65 \\
10. & Kejelasan luaran pembelajaran & $3 \cdot 77$ \\
11. & Rumusan pernyataan yang mudah dipahami & 3.85 \\
12. & Pengunaan kata dan kalimat yang jelas & 3.88 \\
\hline
\end{tabular}

Tabel 2. Hasil Penilaian Ahli (expert judgment) terhadap model pendidikan karakter model SPS

\begin{tabular}{clc}
\hline No. & \multicolumn{1}{c}{ Aspek Penilaian } & Rerata Skor \\
\hline 1. & Obyektivitas materi pembelajaran seni budaya dan keterampilan & 3.85 \\
2. & Obyektivitas panduan model pembelajaran & 3.78 \\
3. & Obyektivitas instrumen pengumpulan data & 3.88 \\
4. & Kepraktisan instrumen pengukuran keterampilan sosial & 3.65 \\
5. & Kepraktisan materi pembelajaran seni budaya dan keterampilan & 3.75 \\
6. & Kepraktisan panduan implementasi model & 3.77 \\
7. & Ekonomis dalam penggunaan waktu & 3.78 \\
8. & Ekonomis dalam penggunaan biaya & 3.75 \\
9. & Ekonomis dalam penggunaan tenaga & 3.78 \\
\hline & Rerata Total Skor & 3.78 \\
\hline
\end{tabular}

Penilaian ahli (expert judgment) terhadap kelayakan model pendidikan karakter model sosial problem-solving, maka rerata skor menunjukkan hasil 3.78 atau katagori baik. Semua aspek penilaian menunjukkan katagori baik. Hal ini mengindikasikan bahwa model sosial problem-solving yang dikembangkan untuk pelaksanaan penguatan pendidikan karakter pada siswa SD Muhammadiyah 11 Tanjung Lengkong Jakarta dalam rangka meningkatkan keterampilan sosial adalah layak untuk digunakan dalam uji coba utama maupun operasional lapangan. Apabila dikonsultasikan dengan standar penilaian dalam panduan model pendidikan karakter, maka rerata skor total berada pada interval lebih besar dari 3.4-4.00 termasuk katagori baik atau layak sehingga model SPS dapat digunakan dengan beberapa perbaikan. Untuk mendapatkan model yang lebih baik, maka instrument tetap dilakukan perbaikan. Dengan demikian, sebelum instrument di uji coba pada tahap kedua uji coba skala kecil, maka terlebih dahulu dilakukan perbaikan mengacu pada rekomendasi yang diberikan oleh validator.

Analisa tanggapan para ahli (expert judgment) terhadap kuesioner kedua menunjukkan bahwa para ahli menyatakan tingkat pendapat positif dalam mendukung penguatan pendidikan karakter tinggi setiap titik ( $\mathrm{X}=$ 3.79 ke atas). Tanggapan para ahli menunjukkan rerata skor dari skor 5 untuk kesesuaian masing-masing aspek penilaian. Maka pola penguatan pendidikan karakter model social problem-solving setelah melalui 3 langkah teknik Delphi, menyatakan bahwa aplikasi model social problem-solving sangat cocok untuk aplikasi penguatan pendidikan karakter di masa depan.

Pola pengajaran dalam penguatan pendidikan karakter telah selesai dilaksanakan dalam kegiatan pengabdian masyarakat ini, dengan menggunakan hasil langsung dari tiga tahapan (putaran) secara sistematis menggunakan teknik Delphi. Pada tahap awal, peneliti mengatur pertemuan dengan 12 ahli (kepala sekolah dan guru bidang studi) 
JPPM (Jurnal Pendidikan dan Pemberdayaan Masyarakat), 6 (2), 2019 - 127

Sintha Wahjusaputri, Bunyamin Bunyamin, Tashia Indah Nastiti

untuk menjelaskan kepada mereka tentang pola pengajaran pendidikan karakter pada mata pelajaran seni budaya dan keterampilan yang diinginkan, berdasarkan kuesioner yang disusun oleh peneliti yang kemudian ditanggapi oleh para ahli dan disesuaikan model kurikulum pembelajaran yang ada di SD Muhammadiyah 11 Tanjung Lengkong Jakarta. Keberhasilan prosedur pengumpulan data ini sangat bergantung pada kerjasama para ahli. Seperti penelitian yang yang dilakukan oleh (Chuaratapong, 1999; Sihombing et al., 2018; Silanoi, 2012) keberhasilan teknik Delphi sangat tergantung pada kerja sama dari para ahli. Peneliti harus memilih para ahli yang antusias dan bersedia untuk berpartisipasi dalam kegiatan pengabdian masyarakat dan memiliki cukup waktu untuk meluangkan waktu dalam menjawab kuesioner. Lebih lanjut Chuaratapong (1999) menunjukkan bahwa teknik Delphi itu sangat banyak diakui lingkup pendidikan karena metode pengumpulan pendapat para ahli dapat konsisten dalam memberikan pendapat dan membuat keputusan. Untuk kegiatan pengabdian masyarakat ini peneliti mampu merekrut kelompok sasaran (ahli) yang sepenuhnya memenuhi syarat untuk memberikan tanggapan cerdas dan dapat diandalkan karena tingkat status yang berbeda-beda dari administrator sekolah, pengawas pendidikan dan guru, sehingga memiliki pengalaman dan sudut pandang yang berbeda.

Menurut Murry dan Hammons (1995) temuan penelitian pendidikan karakter akurat dan dapat diandalkan tergantung pada pengetahuan dan kemampuan dan jumlah ahli berpengalaman yang terlibat dalam studi. Jumlah ideal ahli yang digunakan dalam studi, di Murry dan Hammons (1995) pendapat, harus setidaknya 17 atau lebih, dalam kegiatan pengabdian masyarakat ini jumlah ahli (expert judgment) yang terlibat adalah 12 orang yang terdiri dari kepala sekolah, guru bidang studi, guru bimbingan konseling dan staf administrasi yang harus bisa membuat temuan penguatan pendidikan karakter yang lebih akurat dan dapat diandalkan.

Pola penguatan pendidikan karakter telah dapat dilaksanakan dalam kegiatan pengabdian masyarakat ini melalui hasil langsung dari tiga tahapan (putaran) secara sistematis menggunakan teknik Delphi. Pada tahap awal, tim pengabdi mengatur pertemuan dengan 12 ahli (kepala sekolah dan guru bidang studi) untuk menjelaskan kepada mereka tentang pola pengajaran pendidikan karakter pada mata pelajaran seni budaya dan keterampilan yang diinginkan, berdasarkan kuesioner yang disusun oleh peneliti yang kemudian ditanggapi oleh para ahli dan disesuaikan model kurikulum pembelajaran yang ada di SD Muhammadiyah 11 Tanjung Lengkong Jakarta. Keberhasilan prosedur pengumpulan data ini sangat bergantung pada kerjasama para ahli. Seperti penelitian yang yang dilakukan oleh (Chuaratapong, 1999), keberhasilan teknik Delphi sangat tergantung pada kerjasama dari para ahli. Peneliti harus memilih para ahli yang antusias dan bersedia untuk berpartisipasi dalam kegiatan pengabdian masyarakat dan memiliki cukup waktu untuk meluangkan waktu dalam menjawab kuesioner. Lebih lanjut Jaitip menunjukkan bahwa teknik Delphi itu sangat banyak diakui lingkup pendidikan karena metode pengumpulan pendapat para ahli dapat konsisten dalam memberikan pendapat dan membuat keputusan. Untuk kegiatan pengabdian masyarakat ini Tim pengabdi mampu merekrut kelompok sasaran (ahli) yang sepenuhnya memenuhi syarat untuk memberikan tanggapan cerdas dan dapat diandalkan karena tingkat status yang berbedabeda dari administrator sekolah, pengawas pendidikan dan guru, sehingga memiliki pengalaman dan sudut pandang yang berbeda.

Berdasarkan hasil pengolahan data berdasarkan hasil kuesioner para ahli (expert judgment) yaitu kepala sekolah dan guru terhadap pengembangan pendidikan karakter peserta didik SD Muhammadiyah 11 Tanjung Lengkong Jakarta maka ada beberapa langkah yang harus dilakukan yaitu sebagai berikut:

Pertama, pengenalan. Tahap pengenalan merupakan tahap pertama dalam proses pembentukan karakter. Pembentuk karakter peserta didik SD Muhammadiyah 11 Tanjung Lengkong mulai mengenal berbagai karakter yang baik melalui lingkungan keluarga, karena keluarga merupakan lingkungan pertama tempat anak belajar dan membentuk kepribadiannya sejak kecil. Apabila anggota 
JPPM (Jurnal Pendidikan dan Pemberdayaan Masyarakat), 6 (2), 2019 - 128

Sintha Wahjusaputri, Bunyamin Bunyamin, Tashia Indah Nastiti

keluarga memberi contoh yang baik, maka anak juga akan meniru perbuatan yang baik pula. Akan tetapi, apabila keluarga memberi contoh yang tidak baik maka anak juga akan meniru yang tidak baik pula. Misalnya, orang tua memberi contoh selalu disiplin dan tepat waktu dalam segala hal, maka secara tidak langsung si anak akan meniru dan melakukan hal yang sama seperti orang tuanya, selalu tepat waktu dan bersikap disiplin dalam segala hal. Akan tetapi apabila orang tua memberi contoh kepada anak untuk selalu menunda-nunda pekerjaan, maka anak juga akan selalu menunda-nunda apa yang akan ia kerjakan. Maka dari itu keluarga mempunyai peran penting dalam perkembangan kepribadian anak. Melalui tahap inilah seorang anak akan mengenal kebiasaan.

Kedua, pemahaman. Tahap pemahaman berlangsung setelah tahap pengenalan. Setelah anak mengenal dan melihat orang tuanya selalu disiplin dan tepat waktu. Ketiga, penerapan. Melalui pemahaman yang telah di dapatkan dari orang tuanya maka seorang anak akan mencoba menerapkan dan mengimplementasikan hal-hal yang telah diajarkan oleh orang tuanya. Pada awalnya anak hanya sekedar melaksanakan dan meniru kebiasaan orang tuanya. Anak belum menyadari dan memahami bentuk karakter apa yang ia terapkan.

Keempat, pengulangan/pembiasaan. Didasari oleh pemahaman dan penerapan yang secara bertahap di lakukan, maka secara tidak langsung seorang anak akan terbiasa dengan kedisiplinan yang diajarkan oleh orang tuanya. Pembiasaan ini juga harus diimbangi dengan konsistensi kebiasaan orang tua. Apabila orang tua tidak konsisten dalam mengajarkan pembiasaan, maka anak juga akan melakukannya dengan setengahsetengah. Apabila anak sudah tebiasa, maka hal apapun jika tidak ia lakukan dengan tepat waktu maka dalam hatinya ia akan merasakan kegelisahan.

Kelima, pembudayaan. Apabila kebiasaan baik dilakukan berulang-ulang setiap hari maka hal ini akan membudaya menjadi karakter. Terminologi pembudayaan menunjukkan ikut sertanya lingkungan dalam melakukan hal yang sama. Kedisiplinan seakan sudah menjadi kesepakatan yang hidup di lingkungan masyarakat, apalagi di lingkungan sekolah.

Pendidikan yang diajarkan oleh guru di sekolah, khususnya mata pelajaran seni budaya dan keterampilan merupakan proses untuk membentuk karakter anak yang kurang baik menjadi yang lebih baik. Sehingga diusia sekolah anak harus selalu dikontrol dan diawasi dengan baik. Sehingga pendidikan yang diperoleh tidak disalahgunakan dan bisa diterapkan serta diaplikasikan dengan baik dan benar. Unsur terpenting dalam pembentukan karakter adalah pikiran karena pikiran, yang di dalamnya terdapat seluruh program yang terbentuk dari pengalaman hidupnya. Program ini kemudian membentuk sistem kepercayaan yang akhirnya dapat membentuk pola berpikirnya yang bisa mempengaruhi perilakunya. Jika program yang tertanam tersebut sesuai dengan prinsipprinsip kebenaran universal, maka perilakunya berjalan selaras dengan hukum alam. Untuk membentuk karakter pada peserta didik memerlukan waktu dan proses yang tepat, agar mampu memahami dan mengimplementasikan dengan tepat juga.

\section{SIMPULAN}

Berdasarkan tujuan kegiatan pengabdian masyarakat, yaitu untuk mengetahui langkah-langkah penguatan model pendidikan karakter bagi Siswa SD Muhammadiyah 11 Tanjung Lengkong Jakarta dan penerapannya, maka dapat diklasifikasikan menjadi enam langkah yang berurutan yaitu:

Pertama, menentukan tujuan pembelajaran. Dalam menentukan proses pembelajaran, seorang guru ingin melaksanakan pembelajaran secara sistematis seusai dengan kompetensi di dalam standar isi mata pelajaran, Hal ini bertujuan untuk menentukan tujuan pembelajaran kognitif, afektif dan psikomotorik peserta didik

Kedua, menentukan nilai-nilai yang dikembangkan standar kompetensi dan kompetensi dasar yang tercantum di dalam standar isi mata pelajaran masih bersifat kognitif. Guru menentukan nilai-nilai yang ditargetkan (nilai target) yang akan diinternalisasi (dihayati) dan diaktualisasikan (diamalkan) oleh peserta didik. Tahapan ini meliputi jujur, mengenal antara yang benar 
JPPM (Jurnal Pendidikan dan Pemberdayaan Masyarakat), 6 (2), 2019 - 129

Sintha Wahjusaputri, Bunyamin Bunyamin, Tashia Indah Nastiti

dan yang salah, mengenal antara yang baik dan yang buruk serta mengenal mana yang diperintahkan, misalnya dalam agama.

Ketiga, menggunakan pendekatan terintegrasi. Guru dituntut mahir dalam memandukan nilai-nilai target ke dalam materi pembelajaran sehingga sesuai untuk mencapai kompetensi bidang studi tetapi juga sekaligus untuk membentuk karakter peserta didik. Tahapan ini meliputi diajarkan untuk peduli terhadap orang lain terutama temanteman sebaya, dididik untuk menghargai dan menghormati hak orang lain, mampu bekerjasama serta mau membantu orang lain.

Keempat, menggunakan metode komprehensif. Metode komprehensif merupakan perpaduan antara dua metode tradisional yaitu inkulkasi (penanaman nilai) dan keteladanan, serta dua metode kontemporer yaitu fasilitas memberikan kesempatan kepada peserta didik untuk melatih membuat keputusan moral.

Kelima, menentukan strategi pembelajaran. Dalam menentukan strategi pembelajaran untuk pendidikan karakter perlu menciptakan situasi belajar yang menyenangkan, aktif, kreatif, bertanggungjawab, dan saling bekerjasama.

Keenam, merancang kegiatan yang dapat mengembangakan keterampilan disetiap mata pelajaran dan aktualisasi nilai target. Metode yang dilakukan dalam mengembangkan pendidikan karakter ini dengan pendekatan komperhensif meliputi: inkulkasi nilai; keteladanan (modeling); fasilitasi (facilitation); dan pengembangan ketrampilan (skill buliding)

Hasil temuan penguatan model pendidikan karakter terjadi peningkatan keterampilan sosial siswa SD Muhammadiyah 11 Tanjung Lengkong makin baik dengan peningkatan rata-rata skor 3.75, perilaku tersebut membawa ketenangan dan kebahagiaan. Sebaliknya, jika program mata pelajaran seni budaya dan keterampilan tidak sesuai dengan prinsip-prinsip hukum universal, maka perilakunya membawa kerusakan dan menghasilkan penderitaan. Oleh karena itu, pola berpikir peserta didik harus mendapatkan perhatian serius dari komunitas sekolah.

\section{UCAPAN TERIMA KASIH}

Ucapan terima kasih diberikan kepada: Pertama, Lembaga Pengabdian dan Pemberdayaan Masyarakat (LPPM) Universitas Muhammadiyah Prof. DR. HAMKA (UHAMKA) yang telah memberikan kepercayaan untuk memberikan bantuan Dana dalam rangka melaksanakan kegiatan pengabdian masyarakat ini. Kedua, Direktur Sekolah Pascasarjana UHAMKA, Prof. Dr. Ade Hikmat, M. Pd.; Ketiga, Kepala Sekolah SD Muhammadiyah 11, Tanjung Lengkong Jakarta, Bapak Drs. H. Dedi Iswantara, M. Pd, Guru-guru beserta Staff Kependidikan yang telah mengijinkan kegiatan pengadian masyarakat ini; dan Keempat, Peserta didik SD Muhammadiyah 11, Tanjung Lengkong Jakarta.

\section{DAFTAR PUSTAKA}

Ahmad, M. (2019). Implementasi pendidikan karakter di madrasah berbasis pesantren (Studi di MA PSA Nurul Amal Bandungan). Universitas Wahid Hasyim Semarang.

Bialik, M., Bogan, M., Fadel, C., \& Horvathova, M. (2015). Character education for the 21st century: What should students learn. Center for Curriculum Redesign.

Boe, O., Bang, H., \& Nilsen, F. A. (2015). Experienced military officer's perception of important character strengths. Procedia - Social and Behavioral Sciences, 190, 339-345. https://doi.org/10.1016/j.sbspro.2015.05. oo8

Chuaratapong, J. (1999). The Delphi research technique. 202.143.130.99\%oA /xoop/modules/news/visit.php?fileid-6

Cronbach, L. J. (1977). Educational psychology. Harcourt Brace Jovanovich.

Doty, J., \& Sowden, W. (2010). Competency vs. character? It must be both! Military Review, $\quad$ 9o(5), $\quad \mathrm{S}_{3} 8$. https://www.questia.com/library/jour nal/1G1-242509816/competency-vscharacter-it-must-be-both

Elkind, D. H., \& Sweet, F. (2004). How to do character education. 
JPPM (Jurnal Pendidikan dan Pemberdayaan Masyarakat), 6 (2), 2019 - 130

Sintha Wahjusaputri, Bunyamin Bunyamin, Tashia Indah Nastiti

https://www.goodcharacter.com/howto-articles/how-to-do-charactereducation/

Ferdiawan, E., \& Putra, W. E. (2013). ESQ education for children character building based on phylosophy of Javaness in Indonesia. Procedia - Social and Behavioral Sciences, 106, 1096-1102. https://doi.org/10.1016/j.sbspro.2013.12. 123

Gall, M. D., Gall, J. P., Borg, W. R. D., \& Gall, J. P. (2003). Educational research: An introduction (7th ed.). Pearson Education Inc.

Hanani, D. (2016). Pendidikan karakter anak menurut Imam Al-Gazali. Jurnal Ilmiah AL-Jauhari: Jurnal Studi Islam Dan Interdisipliner, $\quad 1(1), \quad 46-53$. http://journal.iaingorontalo.ac.id/inde x.php/aj/article/view/663

Knox, A. B. (1966). Educational psychology. By Lee Cronbach. 2nd edition. New York: Harcourt, Brace and World, 1963. 706 pages. \$7.50. Adult Education, 17(1), 61-64.

https://doi.org/10.1177/o7417136660170 0117

Koellhoffer, T. T. (2009). Character education being fair and honest. Infobase Publishing.

Koesoema, D. (2007). Pendidikan karakter: Strategi mendidik anak di zaman global. Grasindo.

Lickona, T., Schaps, E., \& Lewis, C. (2007). CEP's eleven principles of effective character education. Character Education Partnership.

Mansyur, A. S. (2017). Pengembangan kurikulum berbasis karakter: Konsepsi dan implmentasinya. Jurnal Pendidikan UNIGA, $1(1), \quad 1-9$. http://journal.uniga.ac.id/index.php/J $\mathrm{P} /$ article/view/6

McDermott, E., Graham, H., \& Hamilton, V. (2004). Experiences of being a teenage mother in the UK: a report of a systematic review of qualitative studies. Lancaster University.

Murry, J. W., \& Hammons, J. O. (1995). Delphi: A versatile methodology for conducting qualitative research. The Review of Higher Education, 18(4), 423436.

https://doi.org/10.1353/rhe.1995.00o8

Pemerintah Republik Indonesia. (2010). Kebijakan nasional pembangunan karakter bangsa tahun 2010-2025. Pusat Kurikulum Balitbang Kemdiknas.

Rokhman, F., Syaifudin, A., \& Yuliati, Y. (2014). Character education for golden generation 2045 (National character building for Indonesian golden years). Procedia - Social and Behavioral Sciences, $\quad 141, \quad 1161-1165$. https://doi.org/10.1016/j.sbspro.2014.05 .197

Sanjaya, W. (2015). Perencanaan dan desain sistem pembelajaran. Kencana Prenadamedia Group.

Sihombing, A. J. B., Purwanggono, B., \& Handayani, N. U. (2018). Analisis faktor-faktor yang mempengaruhi keberhasilan implementasi ISO 9001: 2015 pada industri manufaktur. Industrial Engineering Online Journal, $7(1)$.

https://ejournal3.undip.ac.id/index.ph $\mathrm{p} / \mathrm{ieoj} / \mathrm{article} / \mathrm{view} / 20733$

Silanoi, L. (2012). The development of teaching pattern for promoting the building up of character education based on sufficiency economy philosophy in Thailand. Procedia Social and Behavioral Sciences, 69, 18121816.

https://doi.org/10.1016/j.sbspro.2012.12. 131

Uyun, Z. (2012). Resiliensi dalam pendidikan karakter. Prosiding Seminar Nasional Psikologi UMS. http://hdl.handle.net/11617/1769 